\title{
Where Did All the Flowers Go?: Contradictions in world economies
}

\section{WENDY HARCOURT}

A year on from the Development issue volume 52 no 3 on 'Beyond Economics' did we manage, as the journal stated, to 'bring in ordinary peoples' needs rather than market needs as central to economics'? The short answer is, unsurprisingly, we did not, but the long-term answer is that perhaps we can. What is different from a year ago is that in almost all arenas, there is far more openness to the idea that economics needs to take a different pathway. More or less on mainstream economic agendas are issues of equity, gender, environment, fairness, governance and institution building. The ideology of the infallibility of the market has been shaken, even if the search for what set of beliefs and practices to put in its place continues. Around the world we are seeing troubled politicians calling on think tanks of quite different hues from those of the Chicago school. Politics and economics are being contested together as the volatility of financial institutions and fallibility of governments are now so evident.

The focus on this issue of Development volume 53 no 3 on 'Sustaining Local Economies' then is twofold: one to continue the debate on beyond economics bringing in new voices and building on the dynamic discussions of the earlier journal and in various meetings and on-line debates. The second is to document some of the alternatives found in the local economies, which are functioning on the margins of neo-liberal global capitalism.

The journal aims to set out how to understand possible alternatives to global capitalist economies as part of the search for sustainable futures. The articles look at local markets, solidarity economies and care networks as ways to empower people and encourage greater civic agency. From both a rights perspective and critical development perspective, the journal looks at what is happening on the ground and proposes how to develop different modes of production in different parts of the world.

The articles and photo essays from Australia, England, Kenya, Italy, India, Japan, Madagascar, The Netherlands, Peru, Romania, South Africa, Sudan, United States of America,Tanzania and Wales show how people and economies are surviving, whether or not the State is working or what is happening to banks and the private sector. The richness of their experiences from rural Tanzania to urban Bucharest reminds us of the need for much more detailed analysis that is grounded in realities that take us

Development (2010) 53(3), 301-303. doi:10.1057/dev.2010.62 
beyond old ideologies. The authors present an intriguing picture of social and solidarity economies that build on care and community as they probe into what allows local initiatives to flourish and in what ways the imperative of the global market is touching peoples lives and livelihoods.

The message is that sustaining local economics is not just about markets (whether global or local). It is most of all about political, social and cultural change at all levels many of which challenge the institutions that make up the still powerful current economic system.

Even if there is a sense of hope that positive changes can happen, there is also a sense of foreboding about further systemic collapse, and frank mistrust that today's governance system is able to deal with continuing economic instability.

There is something distinctly unsettling in the discussions. Perhaps because the issue is trying to juggle conceptual, policy and practice and the debate ranges from high-level finance to how to nurture care networks. Despite the attempt at optimism, there is a decidedly pessimistic tone. It did strike me that we need to push further about why this is so, and how we can address it, something that the introduction attempts. I also pondered as I was editing, why environment does not figure more highly. Although authors take up key issues such as: the need to secure local livelihoods, better governance, awareness of gender, and all manner of power asymmetries, the issue of sustaining the environment that allows local economies to thrive does not figure highly in the discussion. Only Molly Scott-Cato and Gus Speth mention directly that a priority for the political economy is to sustain both human and natural communities. It is striking how despite the massive problems we are facing it is very hard to bring about a change.

I write this as the Gulf of Mexico oil spill and fraught negotiations of BP and the US and UK governments are permanently changing geopolitical relations as well as damaging local industries and the rich and unique marine life and ecology. The tragedy should forcibly remind us that unchecked economic growth is destructive to nature as 302 well as peoples. We cannot afford to separate out economics and the environment. The levels of consumption among rich nations and people on which our global economies are depending need to be scrutinized more deeply. We need to be much clearer that sustaining local economies is as much about political ecology as about global trade and economic growth. ${ }^{1}$ Developing institutions that are equitable and fair requires us to nurture both the natural environment and the people who live within it.

The journal articles illustrate a vibrancy and ingenuity for economic survival, but there was little about the strains of overwork, pollution, insecurities and its impact on peoples' health and bodies and even less about the stress modern economic production puts on natural resources and environments. Despite all the catastrophic warnings about climate change, it seems that environment and economics are still not being thought through together. Putting people at the centre means recognizing the limits to growth due to environmental constraints that neither high technical science solutions nor economic modelling can counter. As we try to understand the current state we are in, with the recurring economic cycles of boom and bust we need to address more deeply the environmental issue. Perhaps it is not just about putting people at the centre but about putting wellbeing and sustainability at the centre.

I wonder if the Rio +20 Conference to be held in Brazil in 2012, 20 years after the World Summit on Environment and Development or the Earth Summit in 1992, offers us that opportunity? Even if at local levels there have been brave attempts to implement Agenda 21 agreed to in Rio, the current climate, food, economic and care crises point to the need to give far greater attention to systemic failures. Hopefully Rio +20 is making a shot at this, with the conversation built on three pillars of sustainable development: economic growth, social development and environmental protection, in the context of the current global crises. The two themes that have been set for debate among the world's development community are building a green economy in the context of sustainable development and poverty eradication and the need for an institutional framework for sustainable development. The discussions are 
trying to map out what is 'sustainable development governance' and how to end unsustainable consumption of resources. The talk is of sustainability as the 'life support system' of development.

The question is how to push beyond rhetoric, or as the introduction points out how to unsettle the status quo so that we all work responsibly. We need to see climate change as a warning sign of systemic ecological economic and social crises. We have to be sure that the talk of new green growth is not just another form of corporate capitalism, with the same inequalities and power structures.

Deep change, to paraphrase Speth, has to be built on the reality that we will not be able to sustain local economies in the South if we fail to change unsustainable consumption in the North. When the Icelandic volcano Eyjafjallajökull blew in April of this year it had huge impacts but not just on stranded tourists. It also impacted on the local economies hooked up to European trade. For example, the dip in the livelihoods of precariously employed flower pickers of Kenya whose wilted produce could not be delivered to grace European tables when planes into Europe were grounded. This example points to the profound global inequity that lies at the heart of today's development failures and environmental destruction. We have created local economies that are dependent on unsustainable global lifestyles.

The real challenge of development is then, how to change today's economic globalization that thrives on wasteful lifestyles in some parts of the world and ignores ways to improve life chances, comfort and wellbeing of others. It is important to draw out the interconnections between the degradation of ecosystems by unrestrained productivism, the voraciousness of global capitalism, and the increasing vulnerability of particular communities, such as coastal dwellers, urban poor. The 30 June 2010 headline in The Guardian screams out 'Let's take no orders to slash and burn from this G20 club' (Klein, 2010). The demand is that the public refuse the tough cuts to be made in public spending with the protestors' slogan 'we will not pay for your crisis'. And the metaphor of the article's title underscores that neither will or can the environment pay. It is at the expense of local economies and local environments that our unsustainable modern lifestyle is being built. It is urgent that we do not as Klein proposes just take up a 'return to sender' approach and demand (whether on the streets or at the poll) responsibility to governments in our anger at austerity measures. Rather we need to recognize our own responsibilities and be part of the decisions that keep the political and social fabric together by building a very different form of economics that respects both nature and people. The gap between the global and the local is growing and with this also the divide between the formal and informal but the two phenomena operate in parallel yet they depend on one shared commons.

\section{Acknowledgement}

Thank you to Fatma Alloo, Nicola Bullard, Arthur Muliro and Josine Stremmelaar for their helpful comments and suggestions.

\section{Note}

1 As Maude Barlow on 2 July 2010 the eve of G-20 gathering in Toronto pointed out the world has divided into rich and poor as at no time in our history. The richest 2 percent own more than half the household wealth in the world. The richest 10 percent hold 85 percent of total global assets and the bottom half of humanity owns less than 1 percent of the wealth in the world. The three richest men in the world have more money than the poorest 48 countries.' http://www.democracynow.org/2010/7/2/maude.

\section{Reference}

Klein, Naomi (2010) 'Let's take no orders to slash and burn from this G20 club', The Guardian 30 June, p 32. 